\title{
Sundanese Oral Tradition Research Mapin- Undergraduate Theses of Students of Department of Sundanese Education of FPBS UPI
}

\author{
Ruhaliah $^{1}$, Hernawan ${ }^{2}$ \\ $\left\{{ }^{1}\right.$ ruhaliah@upi.edu, ${ }^{2}$ hernawan@upi.edu $\}$ \\ ${ }^{1,2}$ Universitas Pendidikan Indonesia Bandung, Indonesia
}

\begin{abstract}
Undergraduate thesis (skripsi) is the final work of university students. At Departemen Pendidikan Bahasa Sunda (DPBS) UPI, skripsi research is divided into four big categories; those are linguistics, literature, culture, and teaching-learning process. Research conducted in some skripsi are focused in one of the four categories, even though there are also some others which conducted research focusing in combination of two or more categories. This paper is studying students' skripsi related to Sundanese oral tradition, those are research classification based on arts, ritual, and the approach used. Method used in this study is quantitative method. The source of the data consisted of 1.651 titles of students' skripsi. This amount is less than a quarter of the total skripsi made by DPBS students. Based on the inventory, skripsi related to classic Sundanese oral tradition mostly focused on wawacan with 69 titles and folktale (57).
\end{abstract}

Keywords: Ceremony, Oral Tradition, Skripsi

\section{INTRODUCTION}

Departemen Pendidikan Bahasa Sundaor Department of Sundanese Education (DPBS) of FPBS UPI was established in 1957 with several changes of name. As an institution which aims to preserve regional language, language used in its students' skripsi are Sundanese, with the exception for abstract that uses three languages, namely Sundanese, Indonesian, and English. The total number of DPBS students' skripsi are counts to 1.651 titles, excluding titles that are not yet to be inventoried since the department has more than 2.000 graduates.

At DPBS FPBS UPI, skripsi research are grouped into four big categories, namely language, literature, culture, and pedagogic. Most of those skripsi studied one scope, though there are some that combined one between the four aforementioned categories. From the total number of inventoried titles, there is no related research mapping yet. Hence, this paper will discuss the mapping of DPBS students' skripsi titles, specifically those related to Sundanese culture studies written up until 2019.

This research studies mapping of students' skripsi titles related to oral tradition existing in Sundanese society, such as (1) description of research results; (2) classification based on text, life cycle, and annual ceremonies, (3) approaches used; and (4) media adaptation results.

This research is important since it (1) could be used as research basis for mapping tradition existing in Sundanese and Nusantara, (2) could be used as a basis to discover the development and mapping Sundanese tradition, (3) could explain students' interest towards tradition, (4) 
could be used to select oral tradition researches as the next research material to avoid repetition, and (5) could be used as comparison with tradition from other regions. This research could also acts as activity report.

This research used quantitative method. The data source consists of DPBS FPBS UPI students' skripsi with the number of 1,651 titles. This number is not based on certain criteria but based on the existing data. However, the data in this research is yet to complete due to the limitation of drafting time.

\section{RESEARCH METHOD}

There are various views stated by experts regarding oral tradition. Some of them considered oral tradition equal to folklore, while some others disagreed. However, for the sake of this research, one of the views was taken.

Sibarani (2016, p. 129) cited Ki-Zerbo's view that oral tradition is a testimony delivered verbally from a generation to the next generation. The testimony was delivered through speech, oration, song, pantun (rhymes), folktale, words of wisdom, ballads, et cetera. Furthermore, it is stated that oral tradition could take various forms such as: 1) oral literary tradition such as tradition of using vernacular, traditional expression, traditional riddles, traditional poetry, telling folktales, singing folk songs, and bestows peerage; 2) folk performance and game tradition such as folk beliefs, folk theatre, folk games, folk dance, customs, ceremony or ritual, and folks' party; 3) traditional ceremony and ritual traditions such as ceremonies related to life cycle (birth, marriage, and death) and ceremonies related with livelihood cycle (planting, nurturing, and harvesting); 4) traditional technologies such as folk architecture, engraving, traditional fertilizer making, traditional handycrafts, traditional tailor, traditional jewellery, traditional food and beverage processing, and traditional medicines compounding; 5) symbolization tradition such as traditional gesture, sound cues for traditional communication, and 6) folk music tradition such as performances of gendang, seruling, and other traditional musical instruments.

Occassionally, some traditions are linked with traditional arts because both of them are closely related. There is various sort of traditional art existing in Sundanese society, whether those that are commonly performed in traditional ceremonies such as cara balen, monggang, ajeng, goong renteng, kodok ngorek, sekaten, and degung klasik; or those that purposed solely for entertainment. The gamelaninstruments includes jenglong, bonang, cecempres (saron degung), and gong. However, those instruments are changing and developing over time. Nowadays those instruments are added with fiddled instruments ( $r e b a b)$, stringed instruments (celempung), and wind instruments (suling). In conclusion, gamelan from the present is similar with tatabeuhan from the past (Atik Soepandi; Enoch Atmadibrata, 1977, hal. 6).

Traditional arts could be studied both as part of performance arts or part of oral tradition. Sedyawati (2015) proposed that oral literature and performance arts are closely related and the levels can be sorted as follows.

a. Pure literature readings, such as mebasan in Balinese culture and macapatan in Javanese culture;

b. Literature readings added with simple gestures and/or limited background music, such as in cekepung and kentrung;

c. Story presenting added with dance movements such as randai in Minangnese culture;

d. Story presenting through scene actualizations with the actors doing dialogue and dance as well as background music. 


\section{RESULT AND DISCUSSION}

In Sidimas data, the number of DPBS FPBS UPI alumni are 2,607 people from the level of Baccalaureate, D2, D3, and S1. However, based on interviews, every batch from the year of 1957 consists of 20 to 30 people. From the number, program D2 and D3 did not write skripsi. Hence, it is estimated that there are more than 1,600 titles of DPBS students' skripsi. According to UPI's academic guidelines, every student is supervised by two supervising lecturers and the lecturers' skills will be adjusted with the written research topic.

For the completion of skripsi writing, students are obliged to collect references from various resources, books, journals, proceedings, and others. Both Sundanese, English, and other languages if needed. But the writing of the skripsi must be in Sundanese, except abstract, quotations of foreign languages, and absorption words. It is important to maintain and pass down local languages as part of cultural wealth.

The traditions of Sundanese are very rich in diversity. Some are in the form of oral texts, performances, or both.

In this paper, the thesis compiled by the students is classified based on the object of study, method, and the level of sacredness whether it is associated with ritual or not. Furthermore, data about the thesis based on oral tradition are presented, which are classified based on oral texts, performances, which are follows.

\subsection{Sundanese Oral Tradition}

Skripsi related to tale or folktales are 49 titles in total. The researches were in the form of inventorying, manuscript transliteration, structural analysis, comparison study, correlation, and students' competence. Tale texts also could act as background story of several important ritual ceremonies and places, such as Bubur Suro ceremony in Rancakalong, Sumedang; Kuda Kosong in Cianjur; Ciburuy site in Garut; and Isola building, where UPI was founded.

Inventorying is very important since gained texts were circulated orally. If it is not inventoried, folktale texts could disappear quickly. Furthermore, with the change of current lifestyle of people of present time who consider folktales less important. Folktales have been inventoried by DPBS students in the form of skripsi from the regions of Argapura, Ciparay, Rajagaluh, Sukaraja, Cisarua, Talaga, Cianjur, Kadudampit, Isola, Sukahaji, Kawali, Ciamis, Ciawi, Karawang Barat, Cimahi Utara, Kadungora, Lembang, Conggeang, Cipunagara, Nagrak, Parongpong, Cigasong Majalengka, Baduy, Tegalwaru Karawang, Cimalaka, Kersamanah Garut, Parung Bogor, and Kuningan.

Beside tale texts from oral source, there are also skripsi that studed tale texts by transliterating texts from Cacarakan letters as conducted by Chandra PK (2003). He transliterated tale texts published in Langensari book then analysed the structure of the text.

The development of tale life in the society is very influencing towards the result of students researches. Since it is in the form of inventorying, the number of tales studied in an area will be depicted in the skripsi, such as:

a. Adang Kosasih (1984) who collected 60 tales, and

b. Sri Rahmayati (1988) who collected 70 tales,

The numbers are considered high for a skripsi research. However, as the time goes by, the result of inventorying numbered up to 20 titles in a research; some of them even only gained 10 titles. There are possibilities that those texts are totally disappeared, replaced by other genre. Of course there are varous factors that could cause it. Therefore, existing texts 
should as soon as possible have recorded, transcribed, and printed to be introduced to the society.

Sisindirangenre (Ind. Pantun) is a perennial genre in Sundanese literature treasury. This old poem has been written in manuscript of Sanghyang Siksa Kandang Karesian and still lives until today. Information technology and electronic media take roles in conserving sisindiran. For the reason, its research is still conducted from time to time. However, since the texts spread orally, up until now there are only 20 skripsi which studied sisindiran texts. Besides, there are also students' research about sisindiran in television programs and sisindiran-making game in android-based smartphones.

Research onmantra in the form of an inventory of the community, text transliteration, analysis of cultural values and learning materials. Total of 18 thesis titles. The mantra genre was once included in the Sundanese Local Content Curriculum, but after the 2013 curriculum, the mantra was not included as subject material anymore because it was not listed back in the curriculum. Therefore, further mantra study is not associated with learning process in the school. In terms of development, the inventory of mantras diminished from time to time. For example, the research conducted by Retty Isnendes in 1998 obtained 183 texts from 33 informants. Whereas in the next skripsi, there aren't much data obtained. Thesis on spells are also available in the form of philological studies, because the text is written in Pegon Arabic script.

Students have been studied mantras that came from regions of Naringgul, Nagrak, Talegong, Cengal, Cimindi, Jingkang, Cipanas, Kotabaru, Situraja, Talun, and Anggacarang.

Other Sundanese oral tradition studied by DPBS students includes taboo (pamali), such as taboo in Baduy (in Kanekes, by Ahmad Kusaeri), taboo for pregnant women (Sri Apiyanti), taboo in Sumedang, taboo in Cicalengka Bandung (Diani Permasih, 2014), and taboo in Subang (Iksan Haris, 2014).

\subsection{Written Literature Spread Orally}

In Sundanese culture, there are written texts that spread orally, such as wawacan and cerita wayang. Usually, both are performed all night long. Wawacan texts are written in the form of manuscripts, commonly use letters of Cacarakan, Pegon, or latin. Wawacan reading performance are called beluk, macapatan, gaok (Majalengka), or Kodiran (Sumedang). Skripsi about wawacan commonly are in the form of transliteration and studies of philology, literature, religion, or culture value. Researches about its performance in S1 students is yet to be found since up until now, it is considered difficult to find a beluk group. The existing beluk group mostly only conducted it in one or two hours. Skripsi related to wawacan texts have 69 titles in total, with two of them studied the form of its performance.

Cerita wayang texts mostly are in the form of its outline while the delivery is based on the dalang's (puppeteer) in narrating the story. Students' research about cerita wayang have 10 titles in total. The research data source commonly are in the form of recordings. The data analysed are its texts ( 8 titles) and its performances ( 2 titles).

\subsection{Oral Tradition Related with Islamic Religion}

In Sundanese culture known as pupujian (praise), hadroh, rudat, and nadoman. These two terms are sometimes considered the same. The text is sung, usually before the adzan or waiting for prayer time. This activity is called nadoman. But in some areas, this was carried 
out during the class promotion program at the Madrasah Ibtidaiyah. Visiting each other between schools and singing nadoman at the school visited.

Research on the praise conducted by DPBS FPBS UPI students all began with an inventory, then analysis and study of teaching materials. Inventory of praise is carried out in Cilamaya, Paseh, Cibaregbeg, Cimaung, Dago, and others. The spread of praise is a picture of religious observance and the joy of literature in Sundanese society.

All studies of praise (pupujian) begin with an inventory, at a pesantren or in a village. After that, the structure and elements of education are analyzed. But there is one different research, namely special praise for the bride and groom, which was done by Ira Siti Faridah. The text is in the form of a script, so the main step of its activity is to transliterate. Thesis on this praise counts a lot because it is spread throughout the West Java and Banten regions, the number is recorded 26 pieces of skripsi.

\subsection{Ritual Oral Tradition}

Skripsi about ceremonies or ritual in Sundanese societies could be categorized in three groups, those are ritual ceremonies, human life cycle, and agriculture.

Arts related with ceremonies includes jentreng in Sumedang, ritus tiwu panganten (Fiet Haryadi), and bebegig Sukamantri. Skripsi related with human life cycle ceremony includes upacara tujuh bulanan (Neneng Jeni), gusaran (Nurlela N), and khitanan (Tita Nurmaya). There is no death-related ceremonies that are studied.

Wedding ceremonies: Sumedang's characteristical Sundanese wedding attire, wedding tradition in Cigugur Bandung, ngeuyeuk seureuh (Cece Suherlan), tradisi parebut seeng in Sukabumi, sawer panganten, ngunjungan, bantayan (Puji), ngaras (Nurizka), and babarit at Kampung Cibenda).

Ceremonies related with ocean includes nadran in Subang, labuh saji ceremonies in Palabuhan Ratu (by Andika Nugraha). Ceremonies related with village thanksgiving such as bubur Suro in Sumedang (Patmah), wuku taun ceremony in Kampung Adat Cigondang, ruwatan bumi, hajat buruan, hajat pareresan (Ucu Herlina), seren taun (Lina Yeti), sedekah tutulak (Euis Siti Fatimah), nyiramkeun pusaka kerajaan Talaga (Isri N), upacara adat panjang jimat (Thohir), Upacara Adat Pésta Badung di Kuningan (Nurul N), Upacara Adat Ngalungsur Pusakaat Kampung Godog (Neng Dini I), Upacara Adat Laku Kungkum Jeung Laku Pépé Suku Dayak Hindu Budha Bumi Sagandu Indramayu (Yendi Apriana), Upacara Ruwatan Bumi Hajat Buruanat Kampung Cikareumbi Desa Cikidang (Dicky Rayadin), Tradisi Ngikisat Desa Karangkamulyan Kabupatén Ciamis (Heryani), Acara Rewahanat Desa Taraju (Susi Susanti), Upacara Adat Kawin Cai at Balong Dalem (Fatimah NF), nyepuh (Krisna A), guar bumi, ruwatan lembur, and sedekah bumi (Dwika Z.)

\subsection{Entertainment-purposed Oral Tradition}

In Sundanese society, there are several names of entertainment using animal names, such as kuda renggong, sasapian, domba Garut, singa depok, and bangkong reang (Nadia F.). Those names had been studied from its aesthetics, semiotics, and learnings.

Performance arts that uses tools are in the form of competitions, though some of them are not. Though they are competitions, those traditions' main purpose is recreation, such as adu domba, pencak silat, and sasapian. There are three skripsi titles related to adu domba, those are dodombaan arts (Nurul), seni raja dogar (Marlina), and badogar (Ginanjar). Thus, even though adu domba is a competition, people of Garut have made it as an art and purposed as 
entertainment. There are nine titles of skripsi related to pencak silat, as well as traditional game in the society.

\subsection{Oral Tradition with No Tools}

In Sundanese society, there are various performance arts that uses tools and no tools. Performance arts without tools includes beluk (reading wawacan, macapat), where the narrator only reads the manuscripts in turns.

The early wawacan was written in the form of manuscripts. Knowledge about manuscripts are introduced to the students of DPBS in the course of Philology at semester 5, including wawacan manuscripts. The final assignment from the course is to search, inventory, describe, and transliterate manuscripts. Some of the assignments are then developed for skripsi. Hence, skripsi related to wawacan is considered numerous even though the work that must be done triples printed literature texts. Besides, there are also students with their own interests to study manuscripts.

The works related to manuscript studies consist of field study (the search of existing manuscripts in the society), transliteration, and analysis (philologically, literally, or other formats). Since transliteration commonly had been started at semester 5, this classic literature genre is one of the most researched compared to other classic literature genres. Studies in this field have 68 titles in total. Studies about wawacan is also very diverse, starting from philology, literature, culture, hermeneutic, and religious studies. It happens because manuscripts' contents are very various that the studies are based on the wawacan texts' content.

There are two manuscripts contained of compilation of mantra, such as those studied by Dede Ruska and Rini Sutanti. Therefore, the study is not just philologic but also those that related with the usage of the mantra.

\subsection{Oral Traditions with Tools}

Oral traditions that utilizes tools are categorized into two groups, those are ritual-related and pure entertainment [17]. Performances related with ritual includes carita pantun and carita wayang, while pure-entertainment performances includes kakawihan and kaulinan.

Skripsi related with carita pantun (saga), its studies was based from its literature, linguistics, culture, and feminism. Up until now, there are 10 skripsis regarding carita pantun. Those studies are then correlated with learning material. Since carita pantun is a text with relatively difficult vocabulary, mostly its learning material is available from high school students. Moreover, students' interest to study carita pantun is very lacking due to its long texts and a lot of archaic vocabulary.

There are five titles of skripsi regarding carita wayang. Its studies consist of structural and philosophy studies. However, none of them are correlated and made into learning material, even though carita wayang itself contains exemplar and educational value. The text analysed is based of Mahabharata original text. Moreover, there are carita wayang texts studied from the genre of novel, as conducted by Udin.

As for skripsi related to kawih and kakawihan (dolanan songs), there are 21 titles. All of them are started from inventorying, then analysed and made into learning material. Kakawihan inventorying gained from Kampung Gintung Desa Mangunkerta Kacamatan Cugenang Kabupaten Cianjur, Kacamatan Cikalong Kulon Kabupaten Cianjur, Desa Pagerageung Kacamatan Pagerageung Kabupaten Tasikmalaya, Desa Kebonkalapa Kecamatan Cisarua 
Kabupaten Sumedang, dan di Kampung Sukaasih Kelurahan Sindangjaya Kacamatan Mandalajati Kota Bandung. All skripsi related to kakawihan are connected with learning.

Besides, there are various oral tradition in the form of arts and functions as entertainment, such as jigprak in Cibungbulang (Imam Rakhman), bringbrung (Dwi Komarasari), ronggeng gunung (Ati N.), cingcowong, gembyung, gondang buhun, sampyong, goong, renteng, reak, japlok, and angklung buncis.

\subsection{Studies about Taboo}

Taboo (pamali) is known by Sundanese society as part of education. Researches about taboo conducted by Diani Permasih (2014), Iksan Haris (2015), and Muhamad Kusaeri (2017).

\subsection{Classification Based on Study Techniques}

Based on obtained data, there are several types of oral tradition skripsi studies as concluded below.

a. Inventorying

Inventorying techniques or types are conducted in texts that are in the form of manuscripts and oral literature. Oral literature texts that denotes the result of inventorying are mantra, tales, kakawihan, pupujian, and sawér. Texts that are in the form of manuscripts are sawér, mantra, and wawacan.

b. Text and context analysis

Skripsi which data source is performance mostly analyse the text and context of the performance; such as development history, actors, tools and media, mantra (if it is a ritual), and many other things.

c. Companion Book

Students' study results that then published as books includes those written by Yuhdiatna, titled Ulikan Sastra Dongeng Rayat Karawang minangka Alternatif Materi Muatan Lokal Sakola di Kabupaten Bandung (1995) (Literature Study of Karawang Folktale as Alternative of Local Content Material in Schools in Bandung District). Tale texts from this skripsi then later published as a book with the title of Dongeng ti Karawang and awarded with Hadiah Sastra Samsudi in the year of 2006. Besides, several tale texts from skripsi have been translated for translation project activities held by Badan Bahasa.

d. Comic Books

Some students' skripsi are transformed from babad tales to comic books, such as:

1) Transformasi Carita Babad Jampang kana Wangun Komik pikeun Ngaronjatkeun Kamampuh Maca Pamahaman: Studi Kuasi Ékspérimén ka Siswa Kelas X SMA Pasundan 8 Bandung Taun Ajar 2017/2018 (Neneng Juwita Sari, 2018)

2) Transformasi Carita Dongeng Si Kabayan Karya M.O. Koesman Kana Wangun Komik Strip Pikeun Bahan Pangajaran Maca Di SMP Kelas IX (Ari Yudi Pratama, 2018)

e. Video Making

Oral tradition research is commonly conducted by utilizing recordings. Hence, even though not specifically included in the ordinance, every student who studied oral tradition is obliged to make recordings, even in the simplest form. The result will be made into learning media.

Based on the previous data, students' skripsi related with oral tradition could be presented into a table as follows. 
Table 1.Amount and Type of Researches

\begin{tabular}{|c|c|c|c|c|c|c|}
\hline \multirow{2}{*}{ No. } & \multirow{2}{*}{ Genre } & \multirow{2}{*}{ Amount } & \multirow{2}{*}{ Inventorying } & \multicolumn{2}{|c|}{ Analysis } & \multirow{2}{*}{$\begin{array}{c}\text { Media } \\
\text { Adoption } \\
\text { Comic }\end{array}$} \\
\hline & & & & Text & Context & \\
\hline 1. & Angklung & 9 & & $\checkmark$ & $\checkmark$ & \\
\hline 2. & Badud & 1 & & $\checkmark$ & $\checkmark$ & \\
\hline 3. & Bangbarongan & 1 & & $\checkmark$ & $\checkmark$ & \\
\hline 4. & Bangkong reang & 1 & & $\checkmark$ & $\checkmark$ & \\
\hline 5. & Bangreng & 1 & & $\checkmark$ & $\checkmark$ & \\
\hline 6. & Bebegig & 1 & & $\checkmark$ & $\checkmark$ & \\
\hline 7. & Belentuk ngapung & 1 & & $\checkmark$ & $\checkmark$ & \\
\hline 8. & Calung & 1 & & & $\checkmark$ & \\
\hline 9. & Carita pantun & 13 & & $\checkmark$ & & \\
\hline 10. & Cingcowong & 2 & & $\checkmark$ & $\checkmark$ & \\
\hline 11. & Dongeng & 57 & $\checkmark$ & $\checkmark$ & $\checkmark$ & $\checkmark$ \\
\hline 12. & Ebeg & 1 & & & & \\
\hline 13. & Kakawihan \& kaulinan & 19 & $\checkmark$ & $\checkmark$ & $\checkmark$ & \\
\hline 14. & Mantra & 18 & $\checkmark$ & $\checkmark$ & $\checkmark$ & \\
\hline 15. & Sisindiran & 22 & $\checkmark$ & $\checkmark$ & $\checkmark$ & \\
\hline 16. & Wawacan, beluk, gaok & 69 & $\checkmark$ & $\checkmark$ & $\checkmark$ & \\
\hline 17. & Wayang (golek, landung) & 11 & $\checkmark$ & $\checkmark$ & $\checkmark$ & \\
\hline 18. & $\begin{array}{l}\text { Arts in the form of drama and dances } \\
\text { (longer, topeng banyet, gending } \\
\text { karesmen, bajidoran, lontang, lenong) }\end{array}$ & 8 & & & & \\
\hline 19. & $\begin{array}{l}\text { Arts related with religion of Islam } \\
\text { (pupujian, rudat, kacapi, solawatan, } \\
\text { hadro, tagoni) }\end{array}$ & 31 & $\checkmark$ & $\checkmark$ & $\checkmark$ & \\
\hline 20. & $\begin{array}{l}\text { Magical arts (gesrek, surak ibra, reak, } \\
\text { lais) }\end{array}$ & 4 & & $\checkmark$ & $\checkmark$ & \\
\hline 21. & $\begin{array}{l}\text { Arts as entertainment (ronggeng } \\
\text { gunung, ulin barong, reok, gembyung, } \\
\text { galeong, topeng banjet, topeng kaleng) }\end{array}$ & 10 & & $\checkmark$ & $\checkmark$ & \\
\hline 22. & $\begin{array}{l}\text { Arts as animal imitation: horse } \\
\text { (lumping, bajir, silat, kosong, } \\
\text { renggong, kepang), sheep (adu, } \\
\text { badogar, dodombaan) }\end{array}$ & 4 & & $\checkmark$ & $\checkmark$ & \\
\hline 23. & $\begin{array}{l}\text { Water-related ceremonies (irung-irung, } \\
\text { kawin cai) }\end{array}$ & & & & & \\
\hline 24. & $\begin{array}{l}\text { Ceremonies related with religious day } \\
\text { (Panjang jimat, merlawu, muludan, } \\
\text { nyangku, nyepuh, Rebo wekasan, } \\
\text { ngikis) }\end{array}$ & 7 & & & & \\
\hline 25. & $\begin{array}{l}\text { Ocean-related ceremonies (hajat } \\
\text { laut/nadran) }\end{array}$ & 2 & $\checkmark$ & $\checkmark$ & $\checkmark$ & \\
\hline 26. & $\begin{array}{l}\text { Surroundings-related ceremonies (hajat } \\
\text { buruan sidekah bumi, sidekah tutulak, } \\
\text { hajat makam, guar bumi, hajat sasih, } \\
\text { nyacarkeun jalan, ruatan bumi, wuku } \\
\text { taun, nyuguh, ngaruat coblong) }\end{array}$ & 10 & & $\checkmark$ & $\checkmark$ & \\
\hline
\end{tabular}


27. Ceremonies related with rice and other agriculture (gondang, tutunggulan, tarawangsa, ngekngek, tandur, ngarempug nutu, jentreng, gondang buhun, ngalage, ngaseuk, ngotrek, rendo, ritus tiwu panganten, seren taun)

28. Wedding-related ceremonies (parebut seeng, ngeuyeuk seureuh, ngaras, bantayan, huap lingkung, sungkem, ngunjungan)

29. Ceremonies of pregnancy, birth, and circumcision (babarit, nujuh bulan, marhabaan, gusaran, sawer sundatan)

30. Ceremonies related to death and 
Chart 1. Type of Research

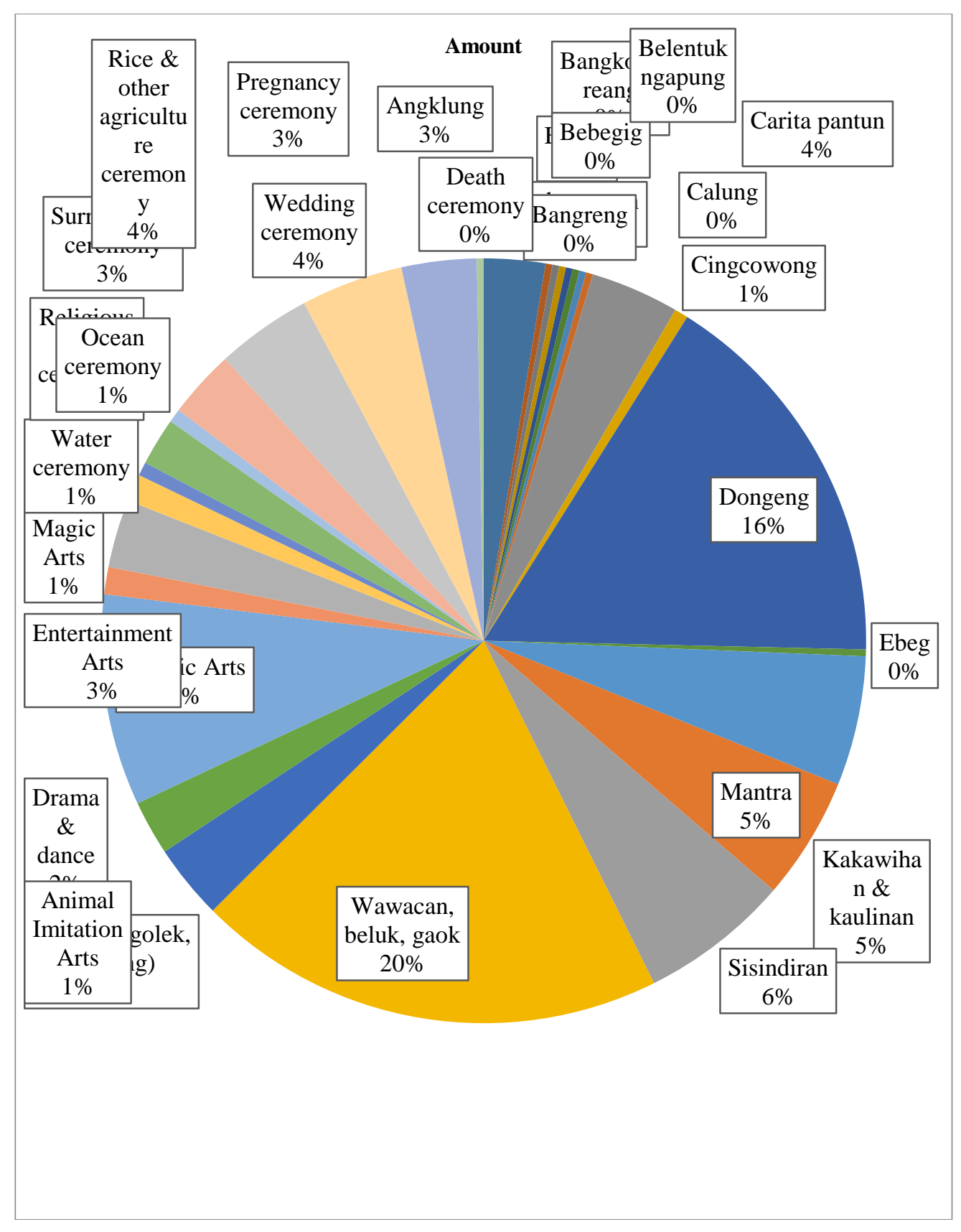




\section{CONCLUSIONS}

Sundanese oral tradition is very various, both its form and its content. DPBS students' interest to study Sundanese oral tradition are mostly focused in tale/folklore, whether they are related to its toponymy or not.

Based on temporary findings, text studies that currently is still lacking must be pushed to be studied so that the texts would not disappear too quickly. Besides, society's richness of literary works or texts is an illustration of its culture's richness. Ritual-related tradition will be lessening over time, as well as the students' courage to study it. Hence, giving motivation is necessary to increase the research.

\section{REFERENCES}

[1] Atik Soepandi; Enoch Atmadibrata. (1977). Khasanah Kesenian Daerah Jawa Barat. Bandung: Pelita Masa.

[2] Cheung, W. M., Chan, S. W., \& Wong, W. Y. (2015). Alice in the multicultural-land: the reading/writing and writing/oracy connection to enhance Chinese competence in literature education. The 10th International Association for the Improvement of Mother Tongue Education (IAIMTE 2015) / The 1st International Association for Research in L1 Education Conference (ARLE), The University of Southern Denmark. Odense, Denmark: The University of Southern Denmark.

[3] Choo, S. S. ( 2014). Towards a transnational model of critical values education: the case for literature education in Singapore . Asia Pacific Journal of Education , 1-15.

[4] Endraswara, Suwardi, P. Y. (2013). Folklor dan Folklife. Yogyakarta: Ombak.

[5] Kosasih, E. (2013). Sastra Klasik sebagai Wahana Efektif dalam Pengembangan Pendidikan Karakter. Bahasa dan Sastra Vol. 13 No. 2.

[6] Patterson, A. (2014). The Legacy of Ian Hunter's Work on Literature Education and . 89-95.

[7] Pudentia MPSS. (2015). Metodologi Kajian Tradisi LIsan. Jakarta: Yayasan Obor Indonesia bekerrja sama dengan Asosiasi Tradisi Lisan.

[8] Ruhaliah. (2019). Sejarah Sastra Sunda (cetakan ketiga). Bandung: DPBD.

[9] Ruhaliah, Moriyama, M., Azis, E. A., Suryadi, K., Muniroh, D. D.-a., \& Yasuda, N. (2015). Pendidikan Karakter dalam Budaya Sunda dan Jepang: Sebuah Kajian Perbandingan. Bandung: UPI - Nanzan University.

[10] Sedyawati, E. (2015). Sastra dalam Kata, Suara, gerak, dan Rupa. Dalam P. MPSS, Metodologi Kajian Tradisi Lisan (hal. 5-10). Jakarta: Obor bekerja sama dengan ATL.

[11] Setyorini, N., \& Riskiana, S. (2017). Kajian Arketipal dan Nilai Kearifan Lokal Legenda di Kota Purworejo serta Relevansinya sebagai Bahan Ajar Mata Kuliah Kajian Prosa. Bahasa dan Sastra Vol. 17 No. 2.

[12] Sibarani, R. (2015). Revitalisasi Folklor sebagai Sumber Kearifan Lokal. Dalam P. Y. Suwardi Endraswara, Folklor dan Folklife dalam Kehidupan Modern (hal. 127-137). Yogyakarta: Ombak Dua.

[13] Sumiyadi. (2012). Relasi Antarteks dalam Pengkajian Sastra. Bahasa dan Sastra Vol. 12 No. 2.

[14] Suryanto, \& Suryanto, E. (2017). Model Pendidikan Karakter Berbasis Pembelajaran Apresiasi Cerita Rakyat dengan Menggunakan Media Wayang Kancil. Bahasa dan Sastra Vol. 17 No. 2. 
[15] Umar, M., Saidu, S., \& Azare, Y. G. (2015). The Impact of Language and Literature Education in Quality Inclusive Education for Sustainable Development in Nigeria. National Journal of Inclusive Education - Vol. 3, No. 1, 99-106.

[16] Wang, W. (2015). A Study of British and American Literature Education Goals Based on Humanistic Quality . English Language and Literature Studies, 160-164.

[17] K. Saddhono and D. Sulaksono, "Indoglish as adaptation of english to Indonesian: change of society in big cities of Indonesia." IOP Conf. Ser.: Ear. and Envi. Sci.. vol. 126 no. 1 IOP Publishing, 2018. 